\title{
PERILAKU HIDUP BERSIH DAN SEHAT (PHBS) TENTANG KEBERSIHAN LINGKUNGAN DI DESA BELEE BUSU DUSUN MEUNASAH DAYAH KECAMATAN MUTIARA BARAT KABUPATEN PIDIE
}

\author{
Idawati $^{1}$, Yuliana ${ }^{2}$, Putri Tutia Rahmi ${ }^{3}$, Fatimah Zuhra $^{4}$, Nurrahmah ${ }^{5}$ \\ ${ }^{1,2)}$ Dosen, Program Studi Diploma Tiga Kebidanan, STIKes Medika Nurul Islam,Sigli, Indonesia \\ ${ }^{3)}$ Mahasiswa Program Studi Diploma Tiga Kebidanan, STIKes Medika Nurul Islam, Sigli, Indonesia \\ ${ }^{4,5)}$ Mahasiswa S1 Keperawatan, STIKes Medika Nurul Islam, Sigli, Indonesia \\ e-mail:pon_ida@yahoo.co.id
}

\begin{abstract}
Abstrak
Perilaku Hidup Bersih dan Sehat (PHBS) adalah sekumpulan perilaku yang dipraktikkan atas dasar kesadaran sebagai hasil pembelajaran. Kesehatan masyarakat dapat dicapai dengan mengubah perilaku dari yang tidak sehat menjadi perilaku sehat dan menciptakan lingkungan sehat di rumah tangga. WHO setiap tahunnya sekitar 2,2 juta jiwa di Negara-negara berkembang terutama anakanak meninggal dunia akibat berbagai penyakit yang disebabkan oleh kurangnya air minum yang aman, sanitasi hygiene yang buruk, pelayanan sanitasi yang memadai, persediaan sanitasi yang memadai, persediaan air yang aman, sistem pembuangan sampah yang memadai dapat menekan angka kematian akibat diare sampai 65\% serta penyakit-penyakit lainnya sebanyak $26 \%$. Data riset kementrian kesehatan diketahui hanya 20 persen dari total masyarakat Indonesia peduli terhadap kebersihan dan kesehatan, dari 262 juta jiwa di Indonesia,hanya sekitar 52 juta orang yang memiliki kepedulian terhadap kebersihan lingkungan sekitar dan dampaknya terhadap kesehatan. Kesadaran masyarakat Indonesia yang masih rendah terhadap kebersihan berpengaruh besar terhadap kesehatan, penyakit Infeksi Saluran Pernapasan Akut (ISPA) dan diare adalah dua penyakit utama yang disebabkan oleh lingkungan hidup yang kurang bersih. Hasil survey di Meunasah Dayah Kecamatan Pidie terdapat 296 KK dengan populasi penduduk berjumlah 1.012 jiwa, dari pengamatan penulis didapatkan keadaan lingkungannya masih kurang bersih dengan dikarenakan masih banyak masyarakat yang membuang sampah sembarangan dan juga banyaknya tumpukan sampah yang menimbulkan bau di sekitar lingkungan.
\end{abstract}

Kata Kunci: PHBS, Kebersihan Lingkungan, Sampah

\begin{abstract}
Clean and Healthy Living Behavior (PHBS) is a set of behaviors that are practiced on the basis of awareness as a result of learning. Public health can be achieved by changing behavior from unhealthy to healthy behavior and creating a healthy environment in the household. WHO annually about 2.2 million people in developing countries, especially children die from various diseases caused by lack of safe drinking water, poor sanitation hygiene, adequate sanitation services, adequate sanitation supplies, adequate water supplies. safe, adequate waste disposal system can reduce the death rate from diere by $65 \%$ and other diseases by $26 \%$. Ministry of Health research data shows that only 20 percent of the total Indonesian people care about hygiene and health, of the 262 million people in Indonesia, only about 52 million people have a concern for the cleanliness of the surrounding environment and its impact on health. The low awareness of the Indonesian people on hygiene has a major effect on health, acute respiratory infections (ARI) and diarrhea are two main diseases caused by an unclean environment. The results of the survey in Meunasah Dayah, Pidie District, there are 296 families with a population of 1,012 people. From the author's observations, it is found that the environmental conditions are still not clean because there are still many people who litter and also the large pile of garbage that causes odors around the environment.
\end{abstract}

Keywords: PHBS, Environmental Cleanliness, Garbage 


\section{PENDAHULUAN}

Perilaku Hidup Bersih dan Sehat (PHBS) merupakan salah satu strategi yang dicanangkan oleh Departemen Kesehatan untuk mencapai tujuan pembangunan Millenium 2015 melalui rumusan visi dan misi Indonesia Sehat, sebagaimana yang dicita-citakan oleh seluruh masyarakat Indonesia dalam menyongsong Milenium Development Goals (MDGs). Perilaku Hidup Bersih dan Sehat (PHBS) merupakan prilaku yang dipraktekkan oleh setiap individu dengan kesadaran sendiri untuk meningkatkan kesehatannya dan berperan aktif dalam mewujudkan lingkungan yang sehat. Perilaku Hidup Bersih dan Sehat harus diterapkan dalam setiap sisi kehidupan manusia kapan saja dan dimana saja. PHBS di rumah tangga/keluarga, institusi kesehatan, tempat-tempat umum, sekolah maupun di tempat kerja karena perilaku merupakan sikap dan tindakan yang akan membentuk kebiasaan sehingga melekat dalam diri seseorang (Kemenkes RI, 2010).

Perilaku hidup bersih dan sehat adalah salah satu strategi yang dapat ditempuh untuk menghasilkan kemandirian dibidang kesehatan baik pada masyarakat maupun pada keluarga, yang artinya harus ada komunikasi antara kader dengan keluarga/masyarakat untuk memberikan informasi dan melakukan pendidikan kesehatan. Ini menjadi tanggung jawab pemerintah kabupaten/kota beserta jajaran sektor terkait untuk memfasilitasi kegiatan PHBS di rumah tangga agar dapat dijalankan secara efektif (Dimyati.A, 2019)

Kesehatan masyarakat dapat dicapai dengan mengubah perilaku dari yang tidak sehat menjadi perilaku sehat dan menciptakan lingkungan sehat di rumah tangga. Oleh karena itu, kesehatan perlu dijaga, dipelihara, dan ditingkatkan oleh setiap anggota rumah tangga serta diperjuangkan oleh semua pihak. Rumah tangga sehat berarti mampu menjaga, meningkatkan, dan melindungi kesehatan setiap anggota rumah tangga dari gangguan ancaman penyakit dan lingkungan yang kurang kondusif untuk hidup sehat (Depkes RI, 2017).

Menurut WHO (2017) setiap tahunnya sekitar 2,2 juta jiwa di Negara-negara berkembang terutama anak-anak meninggal dunia akibat berbagai penyakit yang disebabkan oleh kurangnya air minum yang aman, sanitasi hygiene yang buruk, pelayanan sanitasi yang memadai, persediaan sanitasi yang memadai,persediaan air yang aman, sistem pembuangan sampah yang memadai dapat menekan angka kematian akibat diare sampai $65 \%$ serta penyakit-penyakit lainnya sebanyak $26 \%$. WHO juga mencatat setiap tahunnya setiap sekitar 2,3 juta jiwa di Negara-negara berkembang pelayanan sanitasi yang memadai,persediaan air yang aman, sistem pembuangan sampah yang memadai sebanyak 65\%.Kesadaran masyarakat Indonesia yang masih rendah terhadap kebersihan yang akan berpengaruh besar terhadap kesehatan, penyakit Infeksi Saluran Pernapasan Akut (ISPA) dan diare adalah dua penyakit utama yang disebabkan oleh lingkungan hidup yang kurang bersih.

Data hasil Survey Sosial Ekonomi Nasional (SUSENAS) tahun 2014 menunjukan bahwa di Indonesia sebanyak 38,5\% masyarakat masih merokok di dalam rumah ketika bersama anggota keluarga yang lain. Perokok laki-laki lebih tinggi dari perempuan (72\% dibanding $28 \%$ ). Selanjutnya $77,3 \%$ penduduk usia 15 tahun ke atas kurang melakukan aktifitas fisik, dengan kategori (82\%) kurang bergerak dan (11\%) tidak terbiasa melakukan aktifitas fisik.

Dari data riset kementrian kesehatan diketahui hanya 20 persen dari total masyarakat Indonesia peduli terhadap kebersihan dan kesehatan dari 262 juta jiwa di Indonesia, hanya sekitar 52 juta orang yang memiliki kepedulian terhadap kebersihan lingkungan sekitar dan dampaknya terhadap kesehatan (Kepmenkes RI, 2010).

Manusia perlu menjaga kebersihan lingkungan dan kebersihan diri agar sehat setiap orang harus pandai-pandai menjaga kebersihan tidak sulit menjaga kebersihan lingkungan ada banyak macam cara untuk menjaga kebersihan lingkungan misalnya dengan membuang sampah pada tempatnya, selalu membersihkan selokan air, memisahkan sampah kering dan sampah basah, rajin menyapu halaman rumah,mendaur ulang barang yang tidak terpakai dan masih banyak lagi. Lingkungan menjadi tidak sehat dan dapat mengganggu kegiatan sehari-hari serta menyebabkan penyakit yang menganggu masyarakatapabila tidak dijaga kebersihannya, maka dari itu diharuskan selalu menjaga kebersihan lingkungan karena banyak sekali manfaatnya untuk kehidupan

Berdasarkan dari hasil survey di Di Desa Balee Busu Dusun Menasah Dayah Kecamatan Mutiara Barat Kabupaten Pidie terdapat 296 KK dengan populasi penduduk berjumlah 1.012 jiwa, Desa Balee Busu Dusun Meunasah Dayah memiliki empat dusun, jumlah penduduk berdasarkan jenis kelamin perempuan sebanyak 519 jiwa dan jenis kelamin laki-laki 493 jiwa. Adapun 
berdasarkan pengamatan awal penulis didapatkan keadaan lingkungan di Desa Balee Busu Dusun Meunasah Dayah lingkungannya masih kurang bersih karena masih banyak masyarakat yang membuang sampah tidak pada tempatnya dan juga banyaknya tumpukan sampah yang menimbulkan bau di sekitar lingkungan.

\section{METODE}

Kegiatan ini dilakukan pada bulan September-Oktober 2020 dan berlokasi di Desa Balee Busu Dusun Meunasah Dayah Kecamatan Mutiara Barat Kabupaten Pidie. Penulis dan team memilih menggunakan metode analisis Kualitatif. Tehnik pengabdian masyarakat dengan cara penyuluhan kepada masyarakat yang ada di desa tersebut. Data kualitatif penulis dan team gunakan untuk mengetahui informasi terkait perilaku hidup bersih dan sehat terutama tentang masalah kebersihan lingkungan yang ada di Desa Balee Busu Dusun Meunasah Dayah Kecamatan Mutiara Barat Kabupaten Pidiesecara observasional/survei lapangan dilakukan untuk melihat kondisi nyata yang ada dilapangan sehingga diketahui secara benar atau yang sedang terjadi. Fokus Group Discussion (FGD) dilaksanakan dengan menyertakan beberapa perangkat desa, organisasi yang ada di desa, dan penulis. FGD yang dilakukan memiliki topik tentang pengelolaan perilaku hidup bersih dan sehat terutama mengenai masalah kebersihan lingkungan yang ada di Desa Balee Busu Dusun Meunasah Dayah Kecamatan Mutiara Barat Kabupaten Pidie. Hasil dari wawancara terbuka yang dilakukan dengan kepala Desa Balee Busu Dusun Meunasah Dayah akan dilanjutkan pembahasannya dengan staf Dinas Lingkungan Hidup (DLH) Kabupaten Pidie dan ketua forum Kabupaten Pidie.

\section{HASIL DAN PEMBAHASAN}

Wilayah Desa Balee Busu Dusun Meunasah Dayah terletak didaratan rendah dengan luas 105 Ha, dengan batas-batas wilayah, sebagai berikut:
- Sebelah Utara
: Gp. Rambayan Kupula Kecamatan Peukan Baro
- Sebelah Timur
: Gp. Mee Teungoh
- Sebelah Selatan
: Lingkok Busu
- Sebelah Barat
: Kumbang Busu

Desa Balee Busu Dusun Menasah Dayah Kecamatan Mutiara Barat Kabupaten Pidie memiliki 296 KK dengan populasi penduduk berjumlah 1.012 jiwa, Desa Balee Busu Dusun Menasah Dayah memiliki empat dusun, jumlah penduduk berdasarkan jenis kelamin perempuan sebanyak 519 jiwa dan jenis kelamin laki-laki 493 jiwa.

Desa Balee Busu Dusun Meunasah Dayah Kabupaten Pidie mengalami kendala dalam kebersihan lingkungan terutama mengenai sampah, kebersihan lingkungan disekitar masyarakat tersebut masih kurang bersih karena masih banyak masyarakat yang membuang sampah tidak pada tempatnya dan juga banyaknya tumpukan sampah yang menimbulkan bau di sekitar lingkungan. Mayoritas masyarakat Desa Balee Busu Dusun Meunasah Dayah bekerja sebagai petani di sawah belum memiliki solusi untuk mejaga lingkungannya dengan cara pengolahan sampah dengan baik yaitu membedakan sampah organik dan non organik yang kemudian di buang ke tempat pembuangan sampah sementara (TPS) atau tempat pembuangan akhir (TPA) sehingga masyarakat lebih memilih membakar sampai pada pagi dan malam hari, ada juga yang membuang sampai di pinggir jalan, sunggai, pinggir lapangan, dan selokan sehingga menimbulkan masalah baru yaitu penyumbatan pada selokan yang mengundang jentik-jentik nyamuk.

Dalam teori membuang sampah pada tempatnya merupakan cara sederhana yang besar menfaatnya untuk menjaga kebersihan lingkungan, namun sangat susah diterapkan. Hasil penelitian ini sesuai dengan pernyataan oleh Andang Binawan yang menyebutkan bahwa kebiasaan membuang sampah sembaragan dilakukan hampir di semua kalangan masyarakat, tidak hanya warga miskin, bahkan mereka yang berpendidikan tinggi pun melakukannya. Alasan harus membuang sampah ditempatnya adalah karena sampah adalah suatu bahan yang terbuang atau di buang dari sumber hasil aktivitas manusia maupun alam. Selain kotor, tidak sedap dipandang mata, sampah juga mengundang kuman penyakit. Oleh karena itu sampah harus dibuang di tempat sampah (Saragih, 2015). 


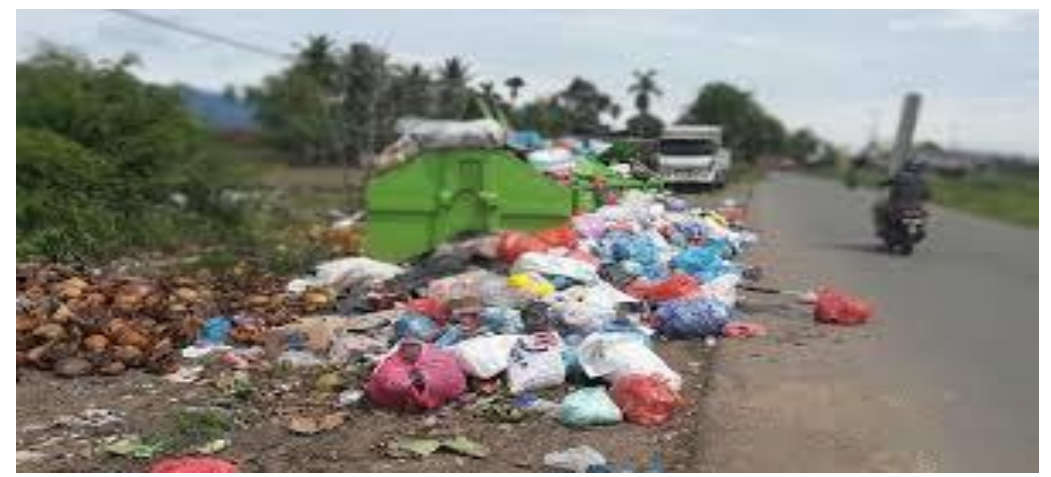

Gambar 1 : Pembuangan Sampah Di Pinggir Jalan

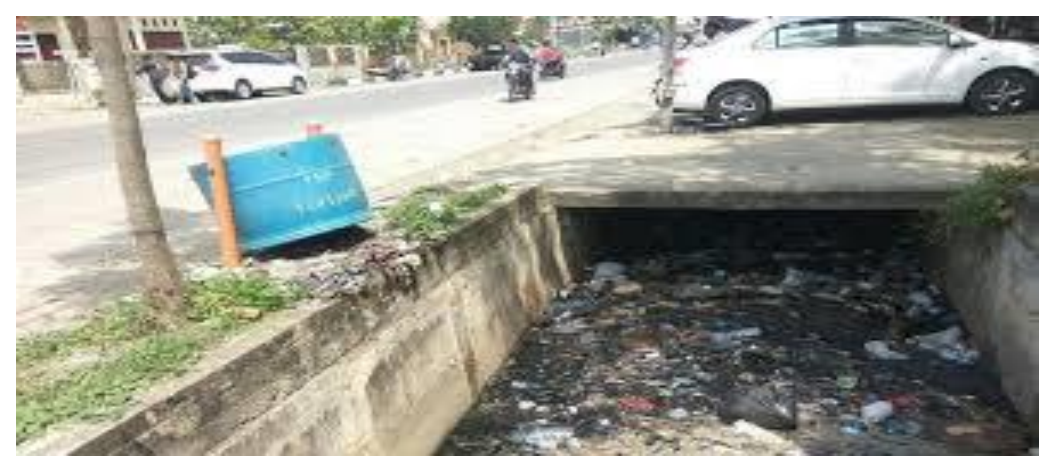

Gambar 2 : Sampah Memenuhi Selokan

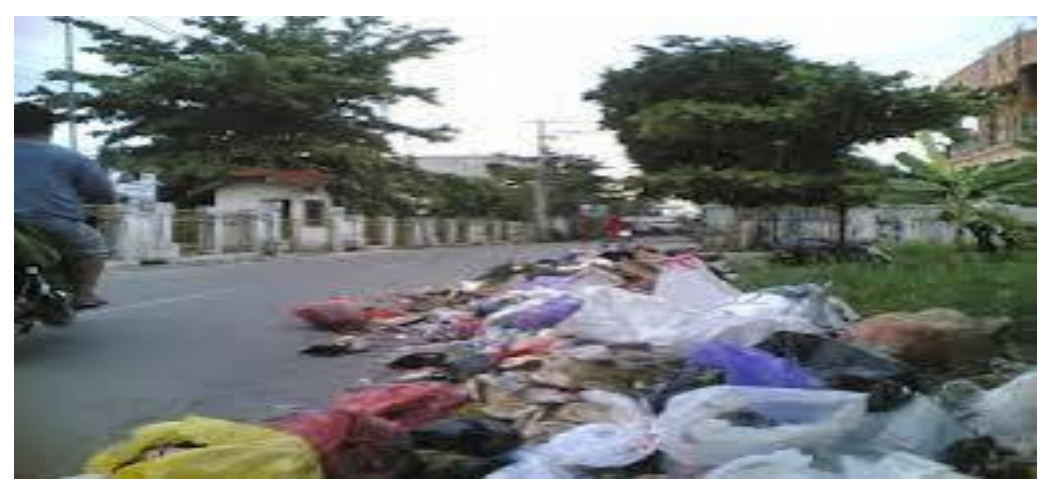

Gambar 3 : Sampah Yang Masih Berserakan Di Pinggir Jalan

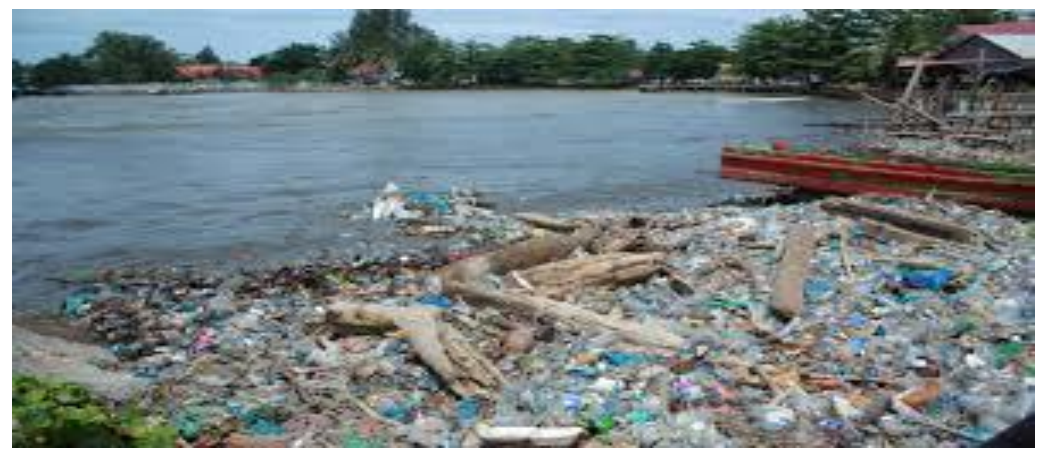

Gambar 4 :Pencemaran Sungai Akibat Sampai Yang Berserakan 


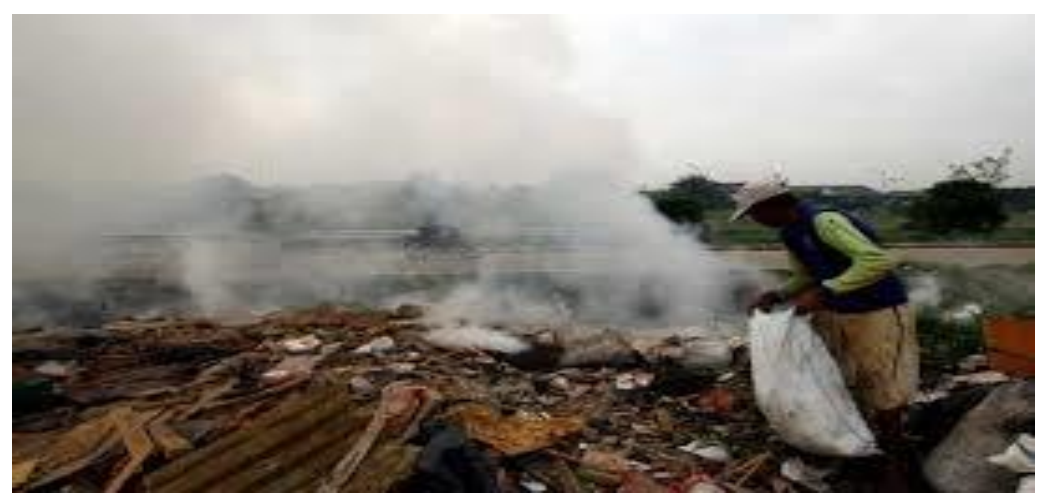

Gambar 5: Pengolahan Sampah Dilakukan Dengan Pembakaran

Kebersihan lingkungan merupakan suatu tindakan yang dilakukan untuk menghilangkan kotoran-kotoran yang ada di lingkungan sekitar. Lingkungan yang sehat (environmental hygiene) menjadi hak bagi setiap masyarakat, yaitu meliputi lingkungan fisik (tanah, air, dan udara), lingkungan biotik (hewan, tumbuhan dan manusia), serta lingkungan sosial (sosial, ekonomi, dan budaya) (Saragih, 2015).

Kesadaran terhadap lingkungan merupakan hal pertama dalam melaksanakan kebersihan peduli lingkungan tidak adanya kesadaran peduli lingkungan maka kebersihan tidak akan pernah tercapai. Kebersihan merupakan syarat bagi terwujudnya kesehatan, dan sehat merupakan salah satu faktor yang dapat memberikan kebahagiaan,sebaliknya jika lingkungan kotor maka akan merusak keindahan tetapi juga dapatmenyebabkan timbulnya berbagai penyakit. Di sekitar pedesaan sampah relatif mudah ditangani karena lahan pembuangan masih mudah dihasilkan, namun terkadang kecerobohan masyarakat membuat masalah ini menjadi serius hingga selain menimbulkan bau yang tidak sedap, berbagai penyakit pun akan timbul karena banyaknya tumpukan sampah yang akhirnya menjadi sarang nyamuk. Selain pembuangan yang sulit didapatkan, minimnya daerah resapan air membuat sampah-sampah menggunung menyumbat saluran air, mengakibatkan air menggenang dan terjadinya banjir.

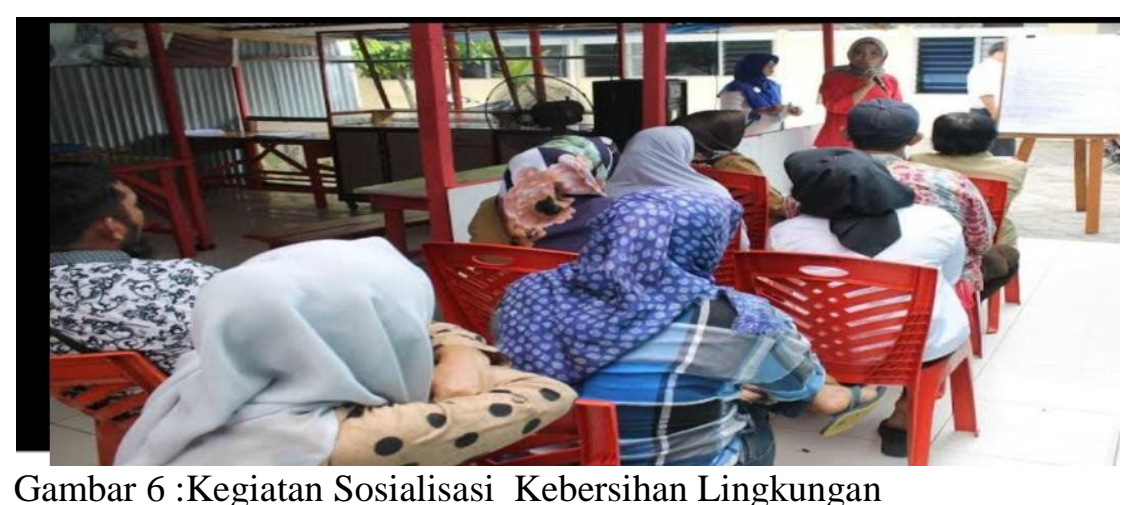

Gambar 6 :Kegiatan Sosialisasi Kebersihan Lingkungan

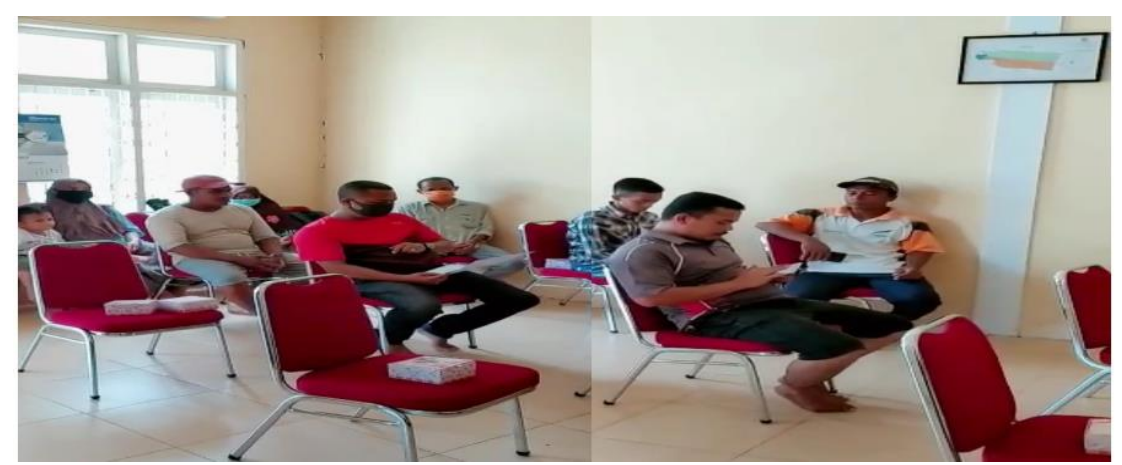

Gambar 7 : KegiatanPerencanaan Sistem Pengelolaan Sampah Bersama Perangkat Desa 


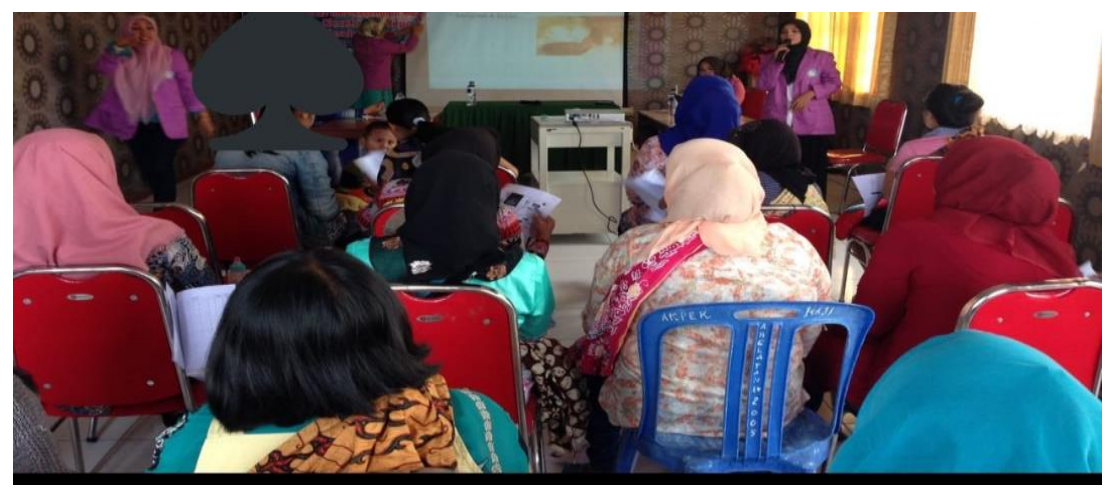

Gambar 8 : Kegiatan Penyuluhan Pembuangan Sampah Rumah Tangga

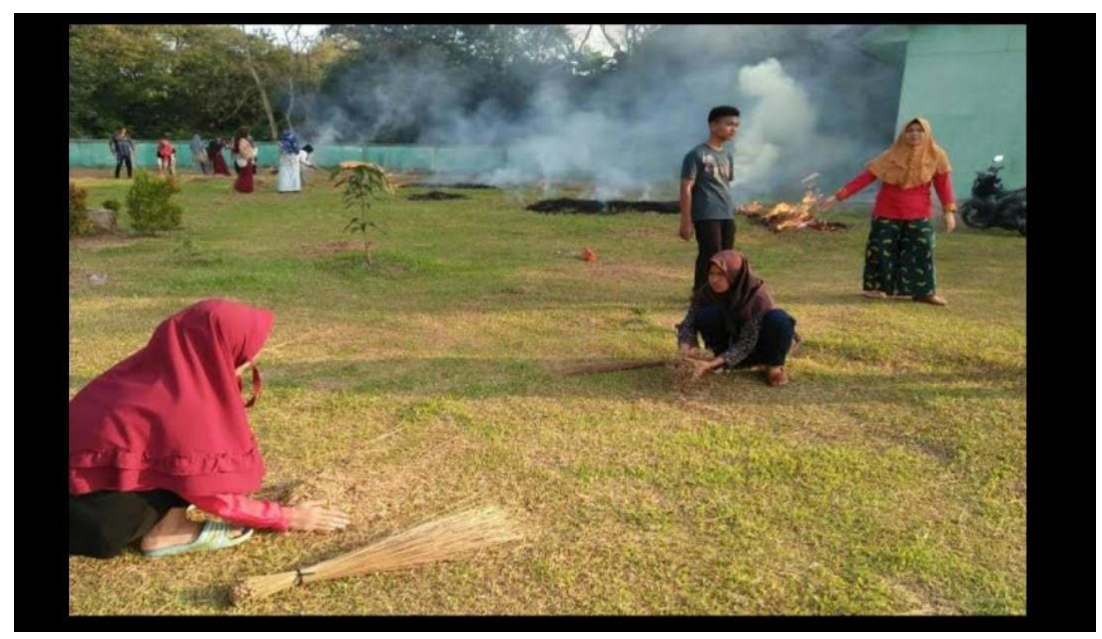

Gambar 9 : Kegiatan Gotong Royong Membersihkan Lingkungan Desa

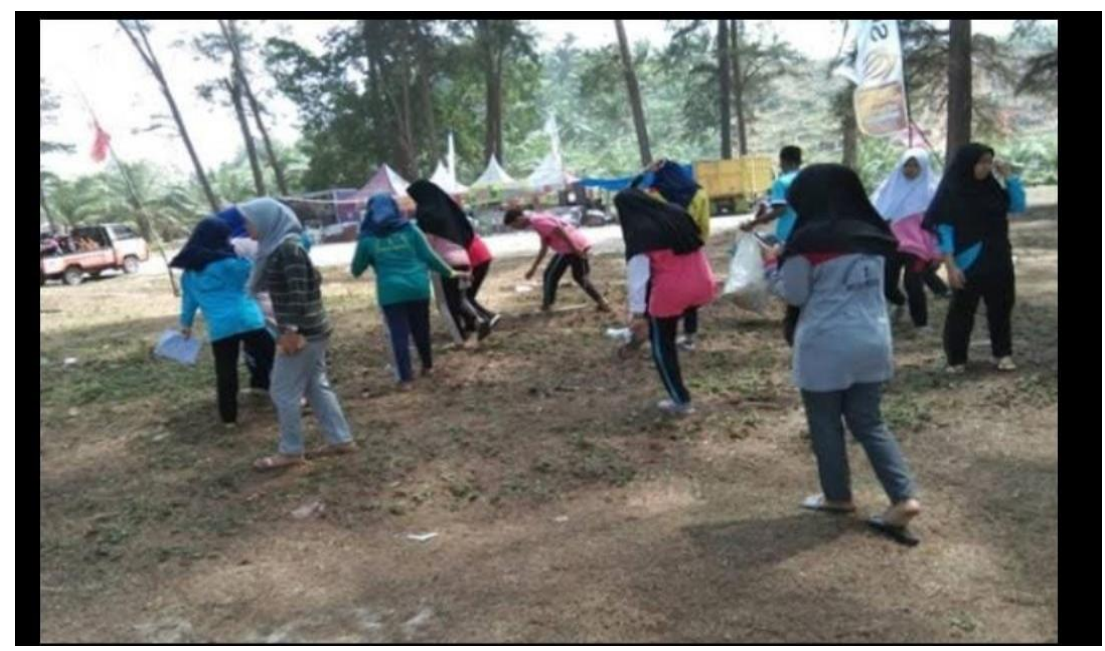

Gambar 10 : Usai Melakukan Senam Kebugaran Remaja Putri Desa Balee Busu Dusun Meunasah Dayah Bergotong Royong Membersihkan Lingkungan 


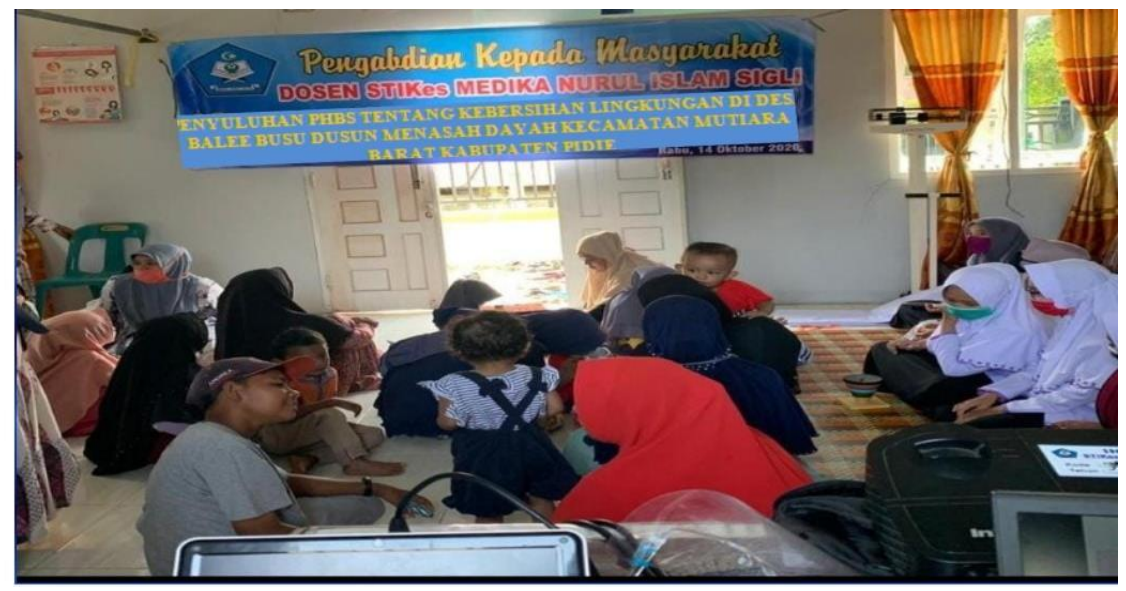

Gambar 11 : Kegiatan Penyuluhan Sekaligus Membahas Kendala Tentang Kebersihan Lingkungan

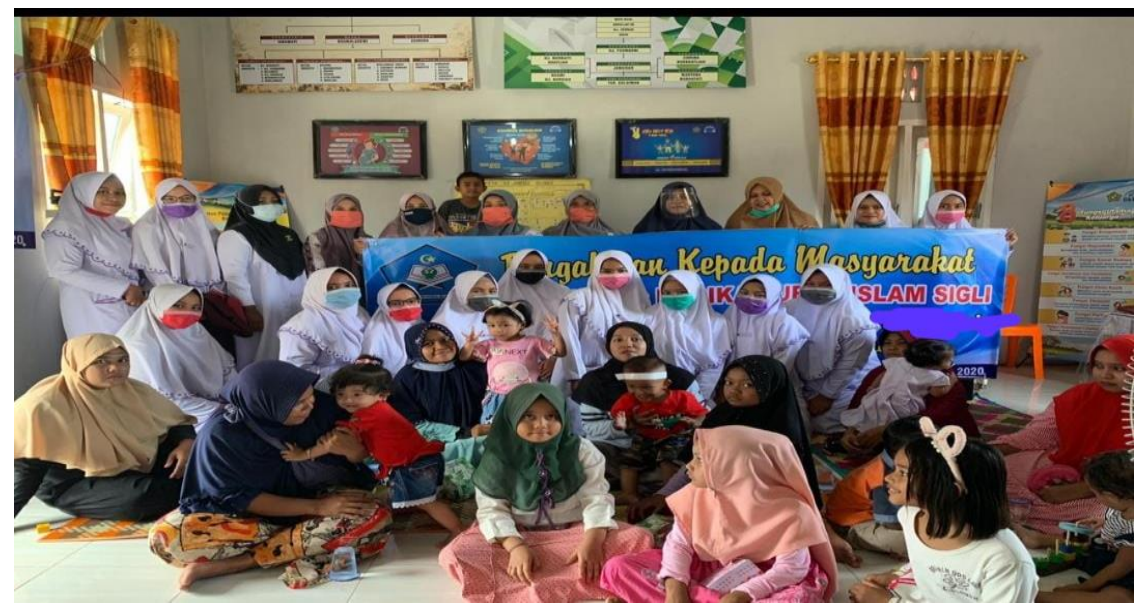

Gambar 12 : Foto Bersama Masyarakat, Dosen STIKes dan Mahasiswa Setelah Mengadakan Kegiatan Penyuluhan Kebersihan Lingkungan

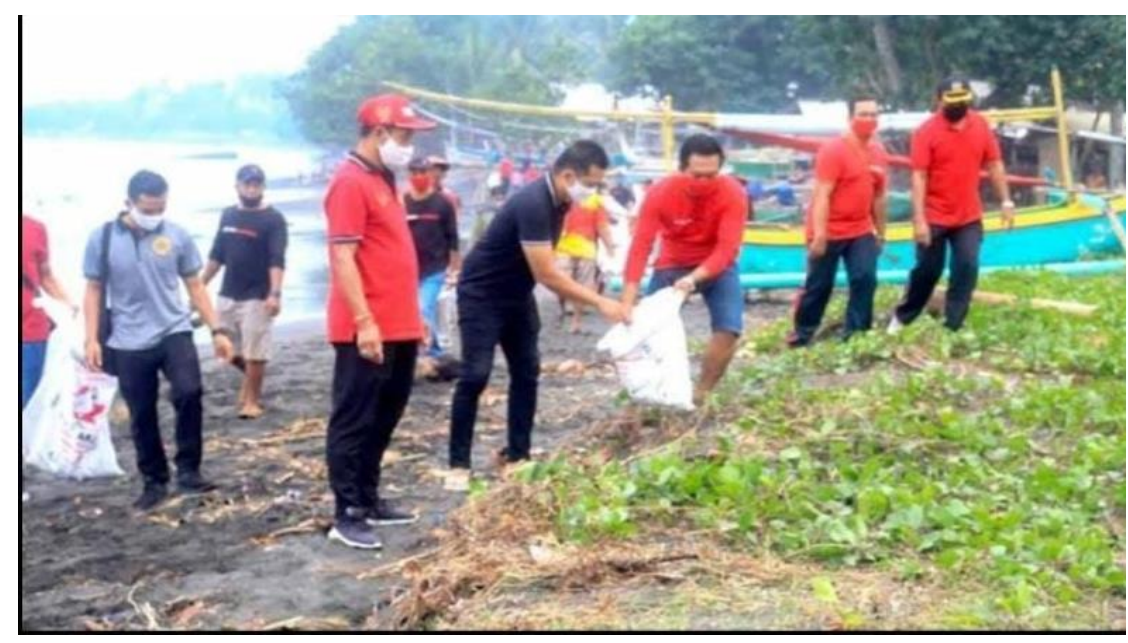

Gambar 13: Kegiatan Masyarakat Bersama Pihak Dinas Lingkungan Hidup (DLH) Dalam Rangka Pembersihan Sungai Dari Sampah 

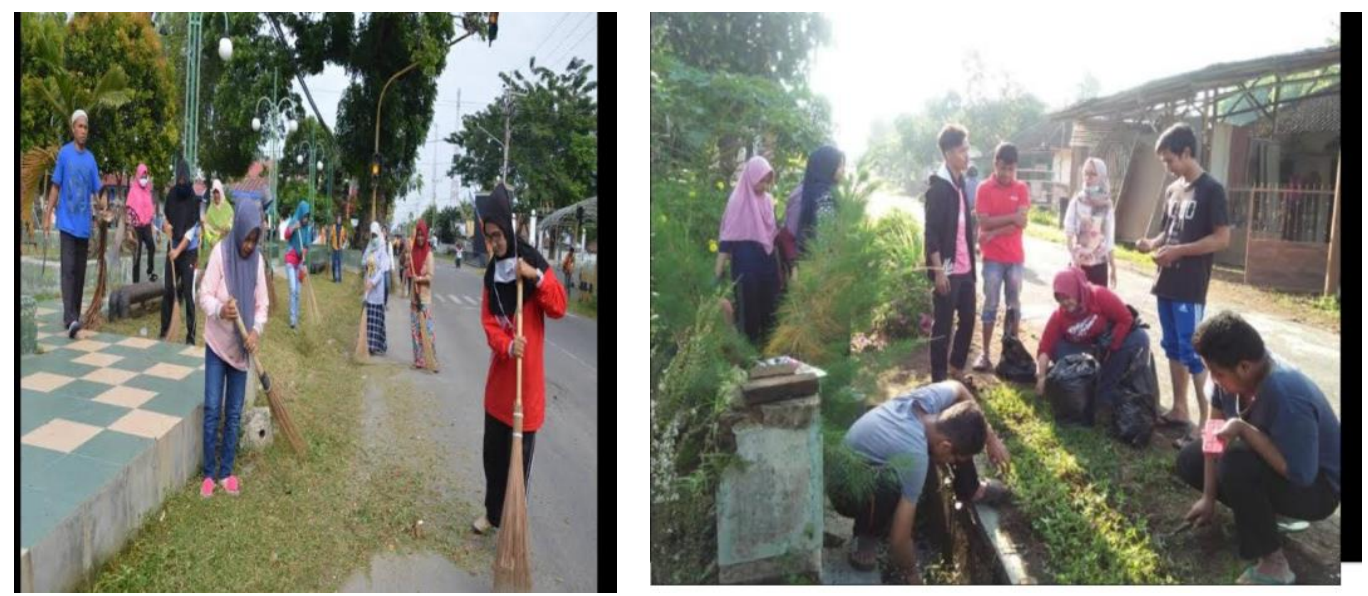

Gambar 14 : Masyarakat Mulai membersihkan Lingkungan Setiap Hari Jum'at (Kegiatan Tersebut Merupakan Hasil Evaluasi Dari Kegiatan Sosialisasi dan Penyuluhan Yang Dilaksanakan Sebelumnya)

Menurut Nurlela, 2017 mengatakan bahwa tempat pengolahan sampah sangat perlu diadakan karena memiliki dampak positif yang lebih besar dari pada dampak negatifnya adanya lahan Desa yang mampu dijadikan Tempat Pembuangan Sampah, maka Desa di desa Meunasah Dayah Kabupaten Pidie hanya menunggu alokasi dana untuk terealisasikanya tempat tersebut dan bekerjasama dengan instansi terkait. Kedua adalah terkait pengelolaan dari sampah tersebut ketika sudah berdirinya Tempat Penampungan Sementara (TPS) di Desa Balee Busu Dusun Menasah Dayah Kecamatan Mutiara Barat Kabupaten Pidie.

Hal ini sesuai dengan penelitian dari Triastantra, 2016 mengatakan bahwa fasilitas yang tidak memadai menjadikan sampah tersebut tidak bisa dikelola dengan baik. Pihak Dinas Lingkungan Hidup (DLH) memberikan masukan berupa penarikan iuran yang nantinya akan meminta tolong orang untuk mengantarkan sampah yang sudah terkumpul ke tempat pembuangan sementara yang sudah disediakan oleh pihak Dinas Lingkungan Hidup (DLH) dan bisa dibawa oleh truk pengambil sampah. Masukan kedua adalah dikarenakan memang akses yang tidak mudah untuk dijangkau, pemusnahan sampah dilakukan dengan cara pembuangan ke lahan kosong yang sudah dapat izin dari pemilik lahan yang nantinya bisa digunakan sebagai pondasi berdirinya suatu bangunan. Sampah tersebut bisa menjadi tambahan unsur untuk suatu bangunan. Masukan ketiga adalah pemusnahan sampah dengan cara dibakar. Hal ini dilakukan sebagai opsi terakhir karena memang tidak bisa dipungkiri bahwa akses jalan ke desa sedang dalam pembangunan. Akan tetapi, pembakaran tidak boleh dilakukan disembarang tempat dan diusahakan yang jauh dari pemukiman sehingga tidak mengakibatkan timbulnya masalah kesehatan baru yang diakibatkan oleh pembakaran sampah tersebut. Ketiga adalah terkait kesadaran masyarakat yang nantinya akan mengelola dan membuang sampah pada tempatnya/Tempat Penampungan Sementara (TPS) yang disediakan. Meningkatkan pola pikir (mindset) dari masyarakat tidaklah mudah dikarenakan ada hal-hal yang dianggap mistis, sudah membudaya, dan lain-lain sehingga perlunya pengaruh yang kuat dari pihak luar. Ketika terjadi pengaruh dari dalam sendiri (internal desa) maka bisa jadi perubahan pola pikir (stigma) tersebut berjalan tidak lebih dari satu minggu. Masyarakat beranggapan bahwa itu sudah menjadi kebiasaan dan orang tersebut pun tidak melakukan hal yang sama dengan apa yang dikatakan sehingga kebiasaan tersebut kembali seperti semula.

Masukan yang diberikan dari pihak Dinas Lingkungan Hidup (DLH) nantinya akan diadakan sosialisai tentang pengolahan sampah yang baik dan benar dikarenakan tingkat kesadaran yang utama adalah pengetahuan seseorang akan hal tersebut. Sosialisasi sudah dilakukan pada awal kegiatan, akan tetapi perlunya sosialisasisecara berkelanjutandari pihak pemerintah/Dinas Lingkungan Hidup (DLH) dikarenakan tingkat kepercayaan masyarakat akan hal itu masih dirasa bisa memberikan dampak positif.

Hal ini sesuai dengan penelitian dari Fajar, 2014 mengatakan bahwa memang tidak mudah merubah suatu perilaku atau kebiasaan dari masyarakat sehingga usaha yang dilakukan harus secara terus menerus (continue) dan dalam waktu yang lama. Keempat adalah terkait pengolahan 
sampah yang bisa dimanfaatkan. Melakukan upaya pemanfaatan sampah yang bisa digunakan sebagai bahan daur ulang adalah salah satu upaya untuk mengurangi sampah. Pada tahun ini sudah tidak lagi malu untuk membuat bahan produk jadi yang berasal dari daur ulang sampah yang masih bisa digunakan dan layak. Dari pihak Dinas lingkungan Hidup (DLH) memberikan masukan berupa adanya pelatihan keterampilan untuk warga dalam melakukan pengolahan sampah. Akan tetapi hal tersebut tidak mudah dilakukan karena tidak semua orang mau berkecimpung dalam dunia persampahan. Pembuatan kompos dari bahan sisa makananyang sudah tidak layak untuk digunakan. Adanya pelatihan ini merupakan upaya yang membutuhkan dorongan dan support yang luar biasa terutama dari dirinya sendiri. Ketika ada keinginan maka semuanya pasti bisa. Kemudian akan dipengaruhi oleh faktor lingkungan sekitar yang mana bisa memperkuat keyakinan atau malah melemahkan keyakinan. Kegiatan pengadaan alat kebersihan dan tong sampahdilakukan pada tahun pertamadikarenakan hal ini merupakan salah satu sarana dan prasarana untuk melakukan dan menjaga kebersihan. Dilakukan pengadaan lagi pada tahun kedua dan ketigauntuk revitalisasi alat kebersihan dan tong sampah yang dianggap sudah tidak layak untuk dipakai.

Kegiatan jadwal rutin bersih desa dilakukan pada tahun pertama harapannnya bisa berlangsung selamanya. Kegiatan jadwal rutin desa ini bisa dilakukan selama satu bulan sekali. Setelah pengadaan alat kebersihan dan tong sampah maka harus dilakukan tindakan yang sebagaimana mestinya. Membangun tempat Sampah Sementara bertujuan agar masyarakat desa bisa membuang sampah di tempat itu dibandingkan sampah yang berasal dari output warga dibakar ataupun dibuang sembarangan.Mengalokasikan anggaran dana desa untuk pembangunan TPS dilakukan pada tahun kedua dan ketiga harapannya bisa terealisasi dan bisa turun pada tahun tersebut sehingga pada tahun berikutnya bisa dilakukan pembangunan Tempat Penampungan Sementara (TPS) di Desa Balee Busu Dusun Meunasah Dayah Kecamatan Mutiara Barat Kabupaten Pidie.

\section{SIMPULAN}

Dari hasil penyuluhan yang dilakukan di Desa Balee Busu Dusun Meunasah Dayah Kecamatan Mutiara Barat Kabupaten Pidie tentang perilaku hidup bersih dan sehat khususnya kebersihan lingkungan, hasil evaluasi yang di peroleh tidak 100\% masyarakat mau mengikuti intruksi dalam menjaga kebersihan lingkungan, salah satuya cara pengelolaan sampai dengan baik, masyarakat menganggap untuk melakukan tindakan penanganan sampai secara arahan dan instruksi membutuhkan waktu yang lama sehingga menghambat pekerjaan lainnya, kemudian masyarakat mampu menjelaskan kembali sebanyak $70 \%$ dari hasil materi penyuluhan yang di berikan dan hanya $75 \%$ masyarakat aktif dan antusias selama jalannya acara penyuluhan.

\section{SARAN}

Diharapkan PHBS di lingkungan masyarakat Desa Balee Busu Dusun Meunasah Dayah Kecamatan Mutiara Barat Kabupaten Pidie dapat terlaksana dengan semaksimal mungkin sehingga para tokoh masyarakat sekitarnya dapat berperilaku hidup yang selayaknya/hidup bersih sehat dalam mejaga kebersihan lingkungan terutama pada pengelolaan sampah.

\section{UCAPAN TERIMA KASIH}

Penulis mengucapkan terimakasih kepada pihak terkait yang telah dan akan melaksanakan program tentang perilaku hidup bersih dan sehat, menjaga lingkungan dengan cara pengelolaan sampah yang baik.

\section{DAFTAR PUSTAKA}

Arsyad, Sitanala dan Ernan Rustiadi. 2008. Konservasi Tanah dan Air Penyelamatan Sumberdaya Air.Bogor: Crestpent Press.

Asdiqoh, Siti. 2011. Etika Islam Terhadap Lingkungan Hidup.Salatiga: STAIN Salatiga Press.

Depkes, RI. 2017. Buku Paket Pelatihan Kader dan Tokoh Masyarakat dalam Pengembangan Desa Siaga. Depkes RI. Jakarta.

Farkhani.2011. Manajemen Lingkungan dan Peran Ulama dalam Mendidik Umat Peduli Lingkungan di Era Otonomi Daerah dalam Hammam (Ed.). Madrasah dan pelestarian Lingkungan sumbangan Konseptual dan Strategi Aksi.Salatiga: STAIN Press. 81-98. 
Kemenkes, RI. 2010. Petunjuk Teknis Pengembangan dan Penyelenggaraan Pos Kesehatan Desa. Pusat Promosi Kesehatan Kemenkes RI. Jakarta Kemenkes RI, 2013. Buku Kurikulum dan Modul Pelatihan Teknis tentang Pengelolaan Advokasi Kesehatan bagi Petugas Promkes. Pusat Promkes Kemenkes. Jakarta

Machfoedz, Mahmud. 2015. Pengantar Pemasaran Modern. Yogyakarta: UPP AMP YKPN Undang-Undang Nomor 23 tahun 1992, Tentang Kesehatan, Penerbit Ariloka, Surabaya.

Mangunjaya, Fachruddin M, Husain Hariyanti dan Reza gholami. 2007. Menanam. Jakarta: Yayasan Obor Indonesia.

Riskesdas. 2013. Riset Kesehatan Dasar. Badan Penelitian dan Pengembangan Kesehatan RI. Jakarta.

Santoso, Imam. 2015. Kesehatan Lingkungan Permukiman Perkotaan.Yogyakarta: Gosyen Publishing.

Saragih Reni. O.V. (2015) Penyuluhan Perilaku Hidup Bersih Dan Sehat. Akademi Kebidanan Kharisma Husada. Binjai

Soemarwoto, Ono. 2001. Atur-Diri-Sendiri Paradigma Baru Pengelolaan Lingkungan Hidup. Yogyakarta: Gadjah Mada University Press.

Sudarsono. 2007. Mengendalikan Dampak Pemanasan Global dengan Kearifan Lingkungan. Yogyakarta: Moko

Sa'di, Adil. 2008. Fiqhun-Nisa Thaharah-Shalat.Jakarta Selatan: PT Mizan Publika.

World Health Organization, 2017. Dampak lingkungan yang tercemar dalam perilaku PHBS. 